\title{
Notch signaling represses GATA4-induced expression of genes involved in steroid biosynthesis
}

\author{
Rajani M George ${ }^{\dagger}$, Katherine L Hahn, Alan Rawls, Robert S Viger ${ }^{1,2}$ and Jeanne Wilson-Rawls \\ School of Life Sciences, Arizona State University, PO Box 874501, Tempe, Arizona 85827-45012, USA, \\ ${ }^{1}$ Reproduction, Mother and Child Health, Centre de Recherche du CHU de Québec and Centre de Recherche en \\ Biologie de la Reproduction (CRBR), Quebec City, Quebec, Canada and ${ }^{2}$ Department of Obstetrics, Gynecology, and \\ Reproduction, Laval University, Quebec City, Quebec, Canada G1K 7 P4
}

Correspondence should be addressed to J Wilson-Rawls; Email: Jeanne.Wilson-Rawls@asu.edu

${ }^{\dagger} \mathrm{R} M$ George is now at GE Healthcare Life Sciences, 7th Floor Brigade Metropolis, Whitefield, Bangalore 560048, India

${ }^{\ddagger} \mathrm{K}$ L Hahn is now at STEMCELL, Ste. 400, 570 West Seventh Avenue, Vancouver, British Columbia, Canada V5Z 1B3

\begin{abstract}
Notch2 and Notch3 and genes of the Notch signaling network are dynamically expressed in developing follicles, where they are essential for granulosa cell proliferation and meiotic maturation. Notch receptors, ligands, and downstream effector genes are also expressed in testicular Leydig cells, predicting a potential role in regulating steroidogenesis. In this study, we sought to determine if Notch signaling in small follicles regulates the proliferation response of granulosa cells to $\mathrm{FSH}$ and represses the up-regulation steroidogenic gene expression that occurs in response to FSH as the follicle grows. Inhibition of Notch signaling in small preantral follicles led to the up-regulation of the expression of genes in the steroid biosynthetic pathway. Similarly, progesterone secretion by MA-10 Leydig cells was significantly inhibited by constitutively active Notch. Together, these data indicated that Notch signaling inhibits steroidogenesis. GATA4 has been shown to be a positive regulator of steroidogenic genes, including STAR protein, P450 aromatase, and 3B-hydroxysteroid dehydrogenase. We observed that Notch downstream effectors HEY1, HEY2, and HEYL are able to differentially regulate these GATA4-dependent promoters. These data are supported by the presence of HEY/HES binding sites in these promoters. These studies indicate that Notch signaling has a role in the complex regulation of the steroidogenic pathway.

Reproduction (2015) 150 383-394
\end{abstract}

\section{Introduction}

It is well established that gonadotropins participate in complex feedback loops required for spermatogenesis and folliculogenesis. Follicle-stimulating hormone (FSH) is important for the development of spermatogonia and steroidogenesis in Leydig cells. FSH also regulates the number of Sertoli and Leydig cells (Baker \& O'Shaughnessy 2001, Baker et al. 2003). During folliculogenesis, granulosa cells respond differently to FSH depending on follicle size. In small preantral follicles, FSH induces granulosa cell proliferation. In larger follicles, however, FSH induces these cells to express the luteinizing hormone receptor and enzymes of the steroid biosynthesis pathway, such as P450 aromatase (Cyp19a1), P450 side chain cleavage enzyme (Cyp11a1), and STAR protein (Star) (Cortvrindt et al. 1997, Robker \& Richards 1998, Spears et al. 1998, Kreeger et al. 2005, Kwintkiewicz et al. 2007). The mechanism(s) by which small follicle granulosa cells are responsive to only the mitogenic activity of FSH remain poorly understood. In preantral follicles, all granulosa cells have active Notch signaling (Johnson et al. 2001, Hahn et al. 2005, Vanorny et al. 2014), and thus, this pathway may mediate the proliferation response of granulosa cells to FSH in growing follicles by suppressing their differentiation and the expression of genes involved in steroidogenesis.

The evolutionarily conserved Notch signaling pathway has been shown to be required for follicle development and fertility. We, and others, have demonstrated that Notch2, Notch3, and the ligands Jagged1 (Jag1) and Jag2 are expressed dynamically in the cells of growing follicles (Johnson et al. 2001, Vorontchikhina et al. 2005, Vanorny et al. 2014). The downstream effector genes Hes1, Hes5, Hey1, Hey2, and HeyL overlap with Notch and its ligands in the granulosa cells (Johnson et al. 2001, Hahn et al. 2005). Several lines of evidence indicate that Notch signaling in the ovary is necessary for granulosa cell proliferation and normal follicle development. In mice deficient for lunatic fringe $(L f n g)$, a modifier of the extracellular domain of the Notch receptors, Notch signaling was 
inhibited in granulosa cells, and these ovaries contained aberrant multi-oocyte follicles (MOFs) that did not undergo meiotic maturation properly (Hahn et al. 2005). In ex vivo ovary culture, the addition of $\gamma$-secretase inhibitors that block Notch signaling resulted in a loss of granulosa cell proliferation (Zhang et al. 2011). Notch2 is necessary for primordial follicle formation (Trombly et al. 2008) and Notch2 deficient ovaries had MOFs that demonstrated a lack of granulosa cell proliferation (Xu \& Gridley 2013, Vanorny et al. 2014). A similar ovarian phenotype was found in mice with an oocyte-specific mutation of Jag1 (Vanorny et al. 2014).

Notch signaling pathway genes are also expressed in the developing testis and juvenile and adult Leydig cells (Dirami et al. 2001, von Schönfeldt et al. 2004, Lupien et al. 2006, Tang et al. 2008, Defalco et al. 2013). During gonadogenesis, Notch signaling regulates the differentiation of Leydig cells from progenitors (Tang et al. 2008). Inhibiting Notch signaling increased the number of Leydig cells, and conversely, expression of constitutively active Notch resulted in a loss of these cells pre- and postnatally (Tang et al. 2008, Defalco et al. 2013). Interestingly, gain- or loss-of-function Notch mutations resulted in both aberrant testis cord formation and loss of germ cells (Tang et al. 2008).

There are four Notch receptors (Notch1-4) in mammals and five ligands: Deltalike1 (D/l1), D/l3, DI/4, Jag1, and Jag2 (Kopan \& Ilagan 2009). On ligand activation, the Notch intracellular domain (NOTCHICD) translocates to the nucleus and binds DNA in a complex with an obligate cofactor, RBPJK (Jarriault et al. 1995, Lu \& Lux 1996, Ong et al. 2006), activating the transcription of its downstream target effectors, the HES and HEY proteins. The HEY and HES proteins are two families of basic helix-loop-helix Orange (bHLH-O) transcriptional repressors (Nakagawa et al. 2000, Iso et al. 2003, Kokubo et al. 2005). In this way, Notch signaling can both activate and repress gene transcription.

The HES and HEY proteins are able to repress transcription through several distinct mechanisms. They can form homodimers that bind to E (CANNTG) or $\mathrm{N}$ (CACNAG) boxes in target promoters and then recruit transcriptional repressor complexes (Sasai et al. 1992, Kageyama \& Nakanishi 1997, Takata \& Ishikawa 2003, Kokubo et al. 2005, Holderfield \& Hughes 2008, Niwa et al. 2011). Alternatively, they can repress transcription through the formation of heterodimers with ubiquitously expressed class A bHLH factors, such as E12 and E47. The sequestration of these factors in nonfunctional heterodimers prevents the formation of heterodimers with tissue-specific bHLH activators, such as MYOD or PARAXIS (Leimeister et al. 2000, Iso et al. 2003). The HEY proteins also form complexes with non-bHLH transcription factors and repress their activity. For example, HEY1 binds to the androgen receptor (Belandia et al. 2005), and HEY2 binds to the aryl hydrocarbon receptor nuclear translocator (Chin et al. 2000). The HEY proteins have also been demonstrated to form complexes with GATA factors and repress expression of genes such as atrial naturietic factor, myosin heavy chain, and Müllerian inhibiting substance through GATA sites (Elagib et al. 2004, Kathiriya et al. 2004, Fischer et al. 2005, Ishiko et al. 2005, Martin et al. 2005, Shirvani et al. 2006, Xiang et al. 2006).

Transcription of genes in the steroid biosynthesis pathway is positively regulated in the gonads by steroidogenic factor 1 (referred to as SF1, gene symbol Nr5a1), a nuclear receptor and CREB/CREM (Ito et al. 1997, Gurates et al. 2003, Ragazzon et al. 2006, Schimmer \& White 2010). In contrast, dosage-sensitive sex reversal adrenal hypoplasia critical region on chromosome $\mathrm{X}$ ( $\mathrm{NrOb} 1$ gene symbol, referred to as Dax1) is a nuclear receptor that acts as a pan transcriptional inhibitor of steroid biosynthetic genes (Tremblay \& Viger 2001a, Wang et al. 2001, Lalli \& Sassone-Corsi 2003, Jo \& Stocco 2004, Manna et al. 2009). Notch signaling could regulate steroid biosynthesis by acting on these regulators of steroidogenesis, either by inhibiting the transcription of SF1 or by up-regulating expression of Dax1.

GATA4, a zinc finger domain transcription factor, has a double zinc finger-binding domain that recognizes the GATA motif in promoters (review Tevosian (2014)). GATA4 is expressed in both Leydig and granulosa cells (Heikinheimo et al. 1997, Viger et al. 1998, 2004, Laitinen et al. 2000, Tremblay \& Viger 2001a,b, Martin et al. 2005, Padua et al. 2014, 2015) and is a key positive transcriptional regulator of genes involved in steroid biosynthesis, including SF1, Cyp19a1, Star, $3 \mathrm{~B}$ hydroxysteroid dehydrogenase (Hsd3b1), and Cyp11A1 (Wooten-Kee \& Clark 2000, Tremblay \& Viger 2001a,b, Tremblay et al. 2002, Bouchard et al. 2005, Martin et al. 2005, Bergeron et al. 2015, Schrade et al. 2015). Notch signaling has been demonstrated to inhibit GATA factor-mediated transactivation of cardiac, hematopoietic, and skeletal muscle specific promoters (Kathiriya et al. 2004, Fischer et al. 2005, Ishiko et al. 2005, Shirvani et al. 2006), indicating that the steroidogenic promoters could also be targets of the Notch pathway.

In the present study, we sought to examine the role of Notch and its HEY downstream effector proteins in the regulation of the expression of genes involved in gonadal steroidogenesis. Our data indicates that Notch signaling inhibits $\mathrm{FSH}$-induced steroidogenic gene expression in small follicles. Also, activated Notch blocked the synthesis of progesterone in cultured MA-10 Leydig cells. A number of genes encoding important enzymes involved in the gonadal steroidogenesis pathway are positively regulated by GATA4 through direct transcriptional activation of the corresponding promoter sequences. We now show that GATA4-dependent activation of these promoters is also a target for 
Notch-mediated repression, further supporting a role for Notch signaling in the control of steroidogenesis.

\section{Materials and methods}

\section{Cells}

MA-10 cells, a Leydig tumor cell line (a kind gift from Dr Mario Ascoli, University of lowa), were cultured in RPMI-1640 (Life Technologies) with 15\% horse serum (GE Healthcare Hyclone, Logan, UT, USA), $20 \mathrm{mM}$ HEPES (Sigma-Aldrich), $4 \mathrm{mM}$ glutamine (GE Healthcare Hyclone), and $50 \mu \mathrm{g} / \mathrm{ml}$ gentamycin (Mediatech, Herndon, VA, USA) on gelatinized plates as described in Mizutani et al. (2006). NIH3T3 cells were purchased from ATCC (Manassas, VA, USA) and cultured in DMEM (Life Technologies) with 10\% newborn calf serum (Atlanta Biologicals, Flowery Branch, GA, USA) and Primocin (Invivogen, San Diego, CA, USA).

\section{Plasmids}

The GATA4 expression plasmid and promoter-luciferase constructs, mouse Star $(-902$ to +17$)$, Cyp19a1 ( -218 to +44), and human HSD3B2 (-224 to +53), have been described elsewhere (Tremblay \& Viger 2001a,b, Tremblay et al. 2002, Martin et al. 2005). The pCS2 + -Notch1ICD and Notch3ICD constructs were kind gifts of Dr Raphael Kopan (Washington University, St Louis, MO, USA). The mouse Notch2ICD (a kind gift of Dr Kathy Loomes, Children's Hospital of Philadelphia, Philadelphia, PA, USA) was cloned into the pCS2 + backbone. The Hey2 expression plasmid and deletion constructs Hey2-62 and Hey2-121 were cloned into the pCS2 + vector and confirmed by sequencing.

\section{Animals}

CD1 mice (Mus musculus) were bred and housed in a vivarium at Arizona State University (ASU) on a $10 \mathrm{~h}$ light:14 h darkness schedule with access to food and water ad libitum. ASU is accredited by the Association for Assessment and Accreditation of Laboratory Animal Care (AALAC). All procedures were carried out in compliance with the ASU Institutional Animal Care and Use Committee and AALAC under an approved research protocol.

\section{Follicle culture}

Ovaries from 14-day-old CD1 mice were harvested and follicles were mechanically isolated using a fine needle. Small preantral follicles that were $\sim 200 \mu \mathrm{m}$ in diameter and had attached theca cells were chosen for culture, as described previously (Murray et al. 1998, Lenie et al. 2004). The follicles were cultured in $\alpha$-MEM (Mediatech) with 5\% FBS (Atlanta Biologicals), insulin, transferrin and selenium (ITS) (Sigma-Aldrich), $50 \mu \mathrm{g} / \mathrm{ml}$ ascorbic acid (Sigma-Aldrich), 0.3\% BSA (Sigma-Aldrich), $2 \mathrm{mM}$ glutamine (GE Healthcare HyClone), and penicillin/streptomycin (Mediatech) in the presence of $200 \mathrm{mIU} / \mathrm{ml} \mathrm{FSH}$ (Sigma-Aldrich) under one of the following conditions: DMSO vehicle only, 25 or $50 \mu \mathrm{M} N$-(N-(3,5-difluorophenacetyl-L-alanyl))-(S)-phenylglycine t-butyl ester (DAPT), a Notch inhibitor (Sigma-Aldrich). Each treatment well received 20 follicles and each treatment was done in duplicate. After $48 \mathrm{~h}$, total follicle RNA was purified for analysis by quantitative RT-PCR (qRT-PCR). The data are the results of three experiments.

\section{Enzyme immunoassay progesterone assay}

MA-10 cells were seeded at $1 \times 10^{5}$ cells/well and cultured as above. These cells were transfected using Fugene6 (Invitrogen) at a $6: 2$ ratio with a maximum of $2 \mu \mathrm{g}$ of DNA. Empty vector was used to equalize total DNA concentration across all transfections. At $48 \mathrm{~h}$ post-transfection the cells were transferred into serum-free medium and treated with $1 \mathrm{mM}$ dibutyryl cAMP (dbcAMP; Sigma-Aldrich) or vehicle for $6 \mathrm{~h}$. The culture medium was collected for enzyme immunoassay (EIA). The concentration of progesterone in the collected medium was determined using an EIA assay per the manufacturer's protocol (Cayman Chemicals, Ann Arbor, MI, USA). Cells were then lysed and RNA was isolated for qRT-PCR.

\section{Quantitative RT-PCR}

MA-10 cells were cultured, transfected, and treated with dbcAMP, as described above. MA-10 cells or intact follicles were lysed in TRIzol (Invitrogen) for RNA isolation, per the manufacturer's protocols. For these studies, three biological replicate experiments were performed. RNA was treated with DNase I and quantified by NanoDrop prior to cDNA synthesis using SuperScriptIII reverse transcriptase (Invitrogen). For each sample, $1 \mu \mathrm{g}$ of RNA was used for cDNA synthesis. The cDNA was quantified using transcript-specific, intron-spanning primers and real-time PCR with Syber Green (Eurogentec, Fremont, CA, USA) on an ABI 7900 HT thermocycler using a 384-well format in $10 \mu \mathrm{l}$ reactions. Products from each primer set were sequenced and analyzed by BLAST (National Center for Biotechnology Information (NCBI)) to verify their identity. Primer efficiency was determined using a standard curve. For each transcript, three biological replicates were assayed in triplicate. All samples were normalized to the Gapdh transcript and relative gene expression was calculated using $\Delta \Delta C q$ analysis (Haimes \& Kelley 2010). For follicle RNA, the control sample was follicles cultured with FSH and vehicle. For MA-10 cells, the control sample was cells cultured without any treatment. Primer sequences for mouse genes are as follows: Gapdh, 5'-GGGAAGCCCATCACCATCTT-3' and 5'-GCCCTTCTCCATGGTGGTGAA-3'; Dax 1, 5'-GCCCTTTTCCTGCTGAGATTC-3' and 5'-TCACAGCTTTGCACAGAGCAT- ${ }^{\prime}$; SF1, 5'-CGCAACAACCTTCTCATTGAGA-3' and 5'-TGGATCCCTAATGCAAGGAGTCT-3'; Star, 5'-AAGCTGTGTGCTGGAAGCTCCTAT-3' and 5'-TGCTTCCAGTTGAGAACCA AGCAG-3'; Hsd3b1 (mouse homolog of human HSD3B2), 5'-ACACAAGGAAGGAATTCTCCAAGCTG- $3^{\prime}$ and 5'-CCTCCAATAGGTTCTGGGTACCTT-3'; Cyp19a1, 5'-CAGCAAGTCCTCAAGCATGTTCCA-3' and 5'-TTCCACCATTCGAAC AAGACCAGG-3'; Hes1, 5'-CAACACGACACCGGACAAACCAAA- $3^{\prime}$ and $5^{\prime}$-TGGAATGCCGGGAGCTATCTTTCT- $3^{\prime}$; and Notch2, 5'-TGCTGTGGCTCTGGCTGT-3' and 5'-TGTGGTAGGTAACACAGGTCCCT-3'. 


\section{Luciferase assays}

NIH3T3 cells were plated at a density of $8 \times 10^{4}$ cells $/ \mathrm{ml}$ in 24-well plates and cultured as described above. Cells were transfected the next day with Lipofectamine and Plus reagent following the manufacturer's protocol (Invitrogen). Each transfected well received $0.05 \mu \mathrm{g}$ of GATA4 expression vector, $0.2 \mu \mathrm{g}$ of steroidogenic gene promoter-luciferase reporter construct, and $0.025 \mu \mathrm{g}$ of plasmids expressing NotchICDs or Hey proteins. All transfections included $0.05 \mu \mathrm{g}$ of $\mathrm{pCMV}$ eGFP (Invitrogen). Total plasmid DNA was kept at $0.4 \mu \mathrm{g} /$ well in all transfections with the addition of empty vector. All assays were done in triplicate on the same plate. The control sample for these assays was transfection of the reporter only. At $48 \mathrm{~h}$ post-transfection, cells were lysed in Luciferase Cell Culture Lysis Buffer (Promega). Luciferase activity was measured for each well by reacting $20 \mu \mathrm{l}$ of cell lysate with $100 \mu \mathrm{l}$ of Luciferase Assay Buffer (Promega) in 96-well plates, using an FLx800 microplate reader (Biotek Instruments, Winooski, VT, USA). All samples were normalized to GFP expression. All data are the mean \pm s.D. of three experiments done in triplicate, and statistical significance was determined using a one-way ANOVA.

\section{Bioinformatics techniques}

Steroid enzyme promoter-luciferase constructs were sequenced and analyzed for the presence of transcription factor binding sites using the TFsearch database (Heinemeyer et al. 1998), which can be found at http://www.cbrc.jp/ cbrc-databases.

\section{Statistical analyses}

All data are the mean \pm s.D. of a minimum of triplicate replicates from three biological experiments. Statistical significance was determined using one-way ANOVA except for qRT-PCR that was analyzed using two-way ANOVA, $P<0.05$ for statistical significance at the $95 \%$ confidence limit.

\section{Results}

$\mathrm{FSH}$ induces both proliferation and expression of steroidogenic genes in granulosa cells depending on follicle size (Robker \& Richards 1998, Kwintkiewicz et al. 2007). Notch2 and Notch3 are expressed in all granulosa cells of small growing follicles (Johnson et al. 2001), and Notch signaling induces proliferation of many cell types, including granulosa cells (Zhang et al. 2011, Vanorny et al. 2014), thus, it is possible that Notch acts downstream of FSH. To examine this, we cultured preantral follicles from 14-day-old CD1 mice in the presence or absence of a Notch inhibitor, DAPT, that blocks ligand-mediated activation of Notch and relieves Notch-mediated repression of gene expression (Fig. 1). Follicles were cultured in the presence of FSH under one of the following conditions: DMSO vehicle only or 25 or $50 \mu \mathrm{M}$ DAPT. After $48 \mathrm{~h}$, total follicle RNA was purified and gene expression was analyzed using qRT-PCR. Hes1, whose transcription is up-regulated by active Notch signaling, was significantly inhibited by DAPT indicating that Notch signaling was blocked (Fig. 1). Conversely, Notch2 expression was increased through a reciprocal signaling pathway, as expected (Vanorny et al. 2014). Genes encoding enzymes important for the synthesis of gonadal steroids - Star, Cyp19a1, and Hsd3b1 (Payne \& Hales 2004) - were significantly up-regulated in follicles cultured in 25 or $50 \mu \mathrm{M}$ DAPT (Fig. 1). These data indicate that Notch signaling inhibits
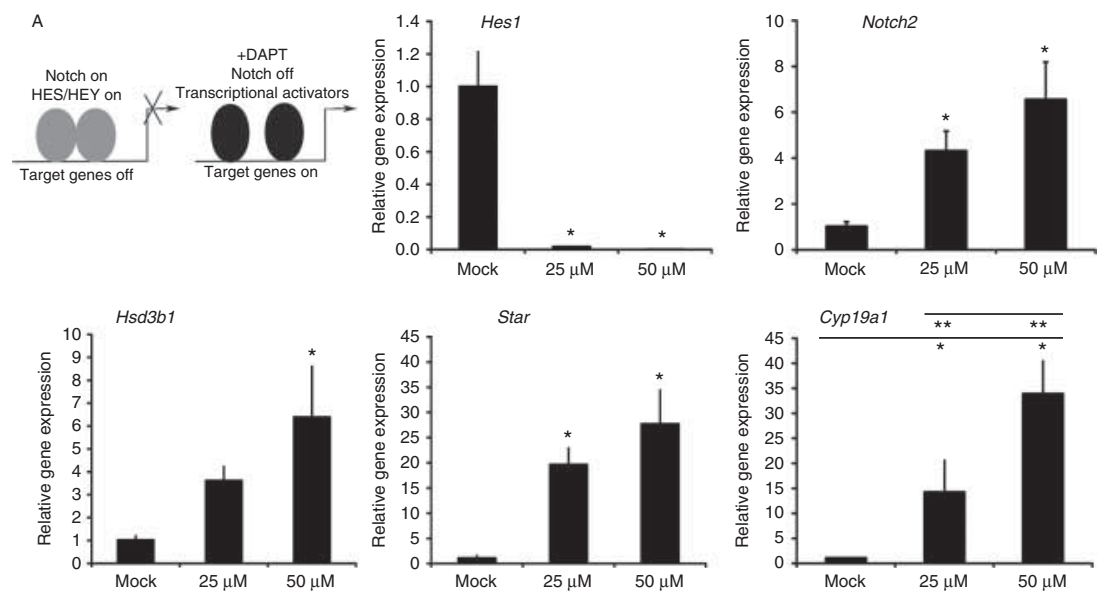

Figure 1 Notch signaling inhibits expression of steroidogenic genes in granulosa cells from preantral follicles. (A) Cartoon describing the assay. Preantral follicles were isolated from 14-day-old CD1 mice and 20 follicles were cultured in the presence of FSH and 0, 25, or 50 $\mu$ M DAPT to block Notch signaling for $48 \mathrm{~h}$. Gene-specific qRT-PCR was done on total follicle RNA. Hes 1 transcription is repressed and demonstrates that DAPT inhibited Notch signaling. Notch2 transcription was increased, as expected. Hsd3b1, Star, and Cyp19a1 demonstrated increased transcription when cultured with FSH and DAPT. Significance was determined by ANOVA, $P<0.05$, *indicates that the sample is statistically different from the mock sample and ${ }^{* *}$ indicates 25 and $50 \mu \mathrm{m}$ DAPT samples are statistically different from each other. Data are the results of three experiments, each done in triplicate. 


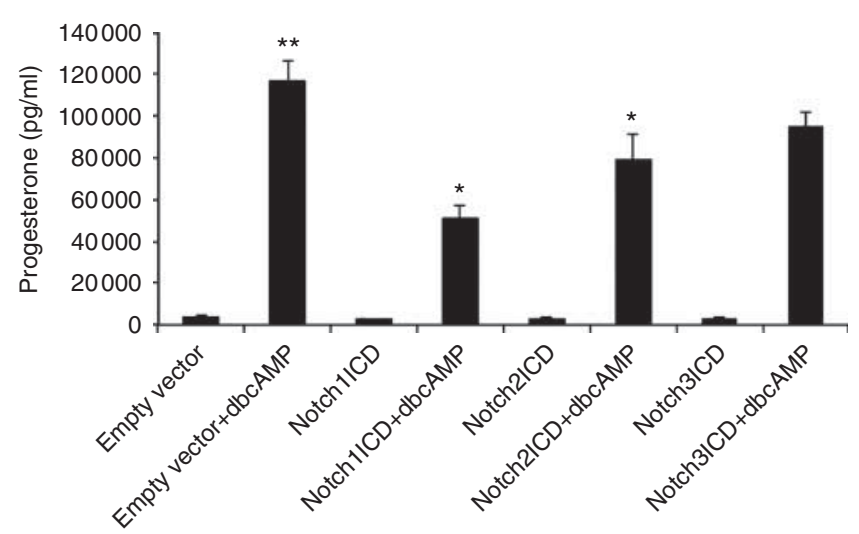

Figure 2 Activated Notch inhibits progesterone secretion in MA-10 cells. MA-10 cells were transfected with a Notch1-3ICD or empty vector. At $48 \mathrm{~h}$ post-transfection, cells were stimulated with dbcAMP to induce steroidogenesis and progesterone was detected in cell supernatants by EIA. Cells transfected with empty vector and treated with dbcAMP secreted a significant amount of progesterone compared to empty vector transfected cells $\left({ }^{* *} P<0.001\right)$. When transfected with Notch1ICD or Notch2ICD, progesterone secretion by dbcAM-treated cells was significantly inhibited, as compared to dbcAMP-treated cells that received empty vector $\left({ }^{*} P<0.05\right)$. Notch3ICD decreased progesterone secretion in the presence of dbcAMP, but not significantly. Transfection with Notch1-3ICD without dbcAMP treatment had no effect on progesterone synthesis. Data are the means \pm S.E.M. of three experiments done in triplicate.

FSH-induced expression of steroidogenic genes in granulosa cells of small preantral follicles.

Because Notch pathway genes are also expressed in Leydig cells, the effect of Notch signaling on steroidogenesis was examined in MA-10 cells, a well-characterized Leydig tumor cell line that synthesizes progesterone when stimulated by hormones or dbcAMP (Ascoli 1981). MA-10 cells were transfected with the constitutively active intracellular domains of Notch1, Notch2, or Notch3. At $48 \mathrm{~h}$ post-transfection the cells were either stimulated with dbcAMP or vehicle and the medium was assayed for progesterone by EIA. Treatment with dbcAMP induced a $>30$-fold increase in progesterone secretion in untransfected cells (Fig. 2). A combination of dbcAMP treatment and transfection of Notch1ICD or Notch2ICD resulted in a significant reduction of progesterone synthesis $\left({ }^{*} P<0.05\right.$; Fig. 2$)$. Notch3ICD followed this trend but was not statistically significant. Therefore, Notch signaling can inhibit synthesis of progesterone in MA-10 Leydig cells.

Since Dax1 and SF1 are central regulators of steroidogenesis, we next determined if their expression was activated or inhibited, respectively, by Notch signaling. MA-10 cells were transfected with plasmids expressing NOTCH1-3ICD and induced with dbcAMP for $6 \mathrm{~h}$, and RNA was isolated for qRT-PCR. As shown in Fig. 3, Dax1 mRNA levels decrease in response to dbcAMP, consistent with the previously reported decrease in protein (Jo \& Stocco 2004, Manna et al. 2009). Transfection with any activated Notch receptor did not block or attenuate this effect. Similarly, neither dbcAMP nor activated Notch receptors had any effect on the expression of SF1 mRNA (Fig. 3). These data suggested that Notch may regulate the promoters of specific genes necessary for steroid biosynthesis because progesterone synthesis was inhibited (Fig. 2).

Whether Notch could mediate repression of specific steroid biosynthesis genes was tested using the wellcharacterized promoters of Star, HSD3B2, and Cyp19a1 PII, which are active in granulosa cells and Leydig cells. These promoters are synergistically activated by GATA4 and SF1 (Tremblay \& Viger 2001a,b, Bouchard et al. 2005, Martin et al. 2005, Kwintkiewicz et al. 2007,
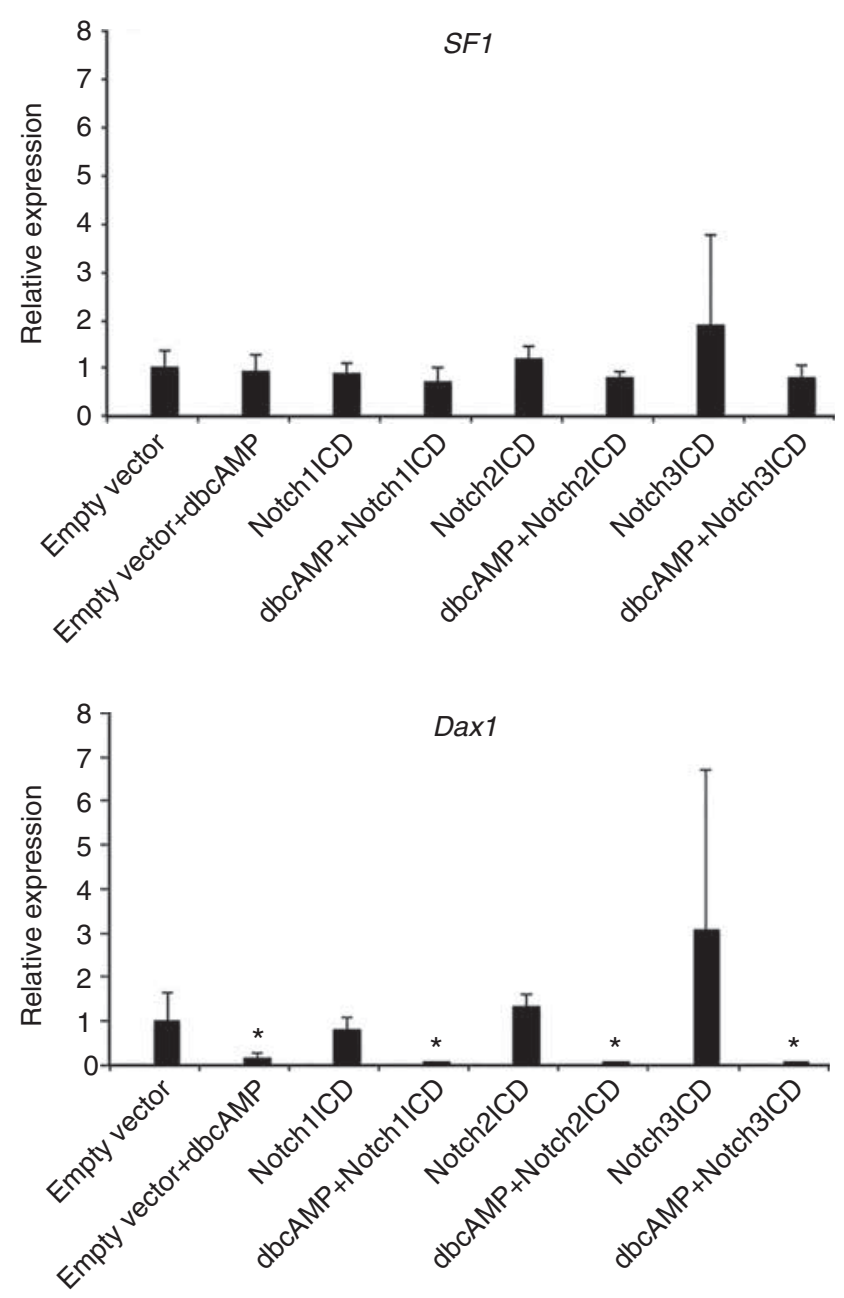

Figure 3 Activated Notch does not inhibit Dax1 or SF1 transcription. MA-10 cells were transfected with plasmids expressing Notch1-3ICD or empty vector and cultured in the presence or absence of dbcAMP, and total RNA was harvested for qRT-PCR using gene specific primers. Dax 1 transcripts are decreased by dbcAMP but not by activated Notch. SF1 transcription was not affected by either dbcAMP or activated Notch. Data presented are the relative expression of three experiments done in triplicate \pm s.D. $* P<0.05$ as compared to untreated MA-10 cells. 
Schrade et al. 2015, Bergeron et al. 2015). Interestingly, GATA4 activity is negatively regulated by HEY2 in the heart and developing cardiovascular system, making it a possible target for Notch signaling in gonadal cells also (Kathiriya et al. 2004, Kokubo et al. 2005). NIH3T3 cells were used in these studies to reduce background signals due to endogenous GATA4, SF1, and DAX1 activity. Cells that were transfected with a plasmid expressing Gata4 and a Star promoter-luciferase reporter gene demonstrated greater than sixfold up-regulation of luciferase activity over the reporter alone. This activity was significantly inhibited by co-transfection with NOTCH1ICD, NOTCH2ICD, or NOTCH3ICD (Fig. 4A). Similarly, both the -222 to +55 HSD3B2- and the -284 to -23 Cyp19a1 PII-luciferase reporters were up-regulated 2.2- and fourfold, respectively, by GATA4. NOTCH1ICD, NOTCH2ICD, and NOTCH3ICD significantly inhibited the ability of GATA4 to activate these promoters (Fig. 4B and C). These observations are consistent with the MA-10 cell data and indicate that activated Notch can repress the promoters of specific genes in this pathway.

Direct transcriptional repression via Notch signaling is mediated by the HES and HEY bHLH-O repressor proteins binding to $\mathrm{N}$ and $\mathrm{E}$ boxes in the promoters of genes (Iso et al. 2003, Grogan et al. 2008, Heisig et al. 2012, Leal et al. 2012). Using TFSearch, an algorithm that searches DNA sequences for enhancer binding sites (Heinemeyer et al. 1998), the promoter regions of Star, HSD3B2, and Cyp19a1 PII were analyzed for $\mathrm{N}$ boxes (CACNAG consensus) and E boxes (CANNTG consensus) that could potentially bind HEY family members. The Cyp19a1 PIl promoter has two E boxes (Fig. 5). The HSD3B2 promoter has a single $\mathrm{N}$ box, CACAAG, but no E boxes. Finally, the Star promoter has an N box and three $\mathrm{E}$ boxes (Fig. 5). The GATA sites have been confirmed as GATA4-binding sites that activate transcription of these genes in other studies (Tremblay \& Viger 2001a,b, Bouchard et al. 2005, Martin et al. 2005).

To determine if the HEY bHLH-O repressors could inhibit GATA4, transcriptional activation of the steroidogenesis gene promoters was tested using a similar approach to the above discussion. As can be seen in Fig. 6A, GATA4 highly induced Star-luciferase activity when transfected into $3 T 3$ cells, and this activity was significantly inhibited by co-transfection with any of the three HEY proteins. Similarly, the HSD3B2 reporter demonstrated a $>11$-fold increase in luciferase activity when co-transfected with GATA4 but was significantly repressed by HEY1 and HEYL only. HEY2 had no effect on the HSD3B2 promoter. Co-transfection of any of the three HEY proteins with the Cyp19a1 PII-luciferase reporter gene and GATA4 showed decreased activity, but only HEY1 inhibited this promoter significantly (Fig. 6C).

HEY proteins also can form complexes with the GATA factors and repress transcription. To determine if HEY2
A
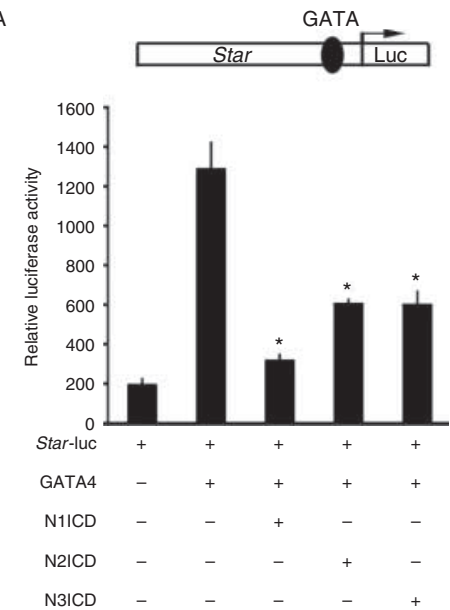

B
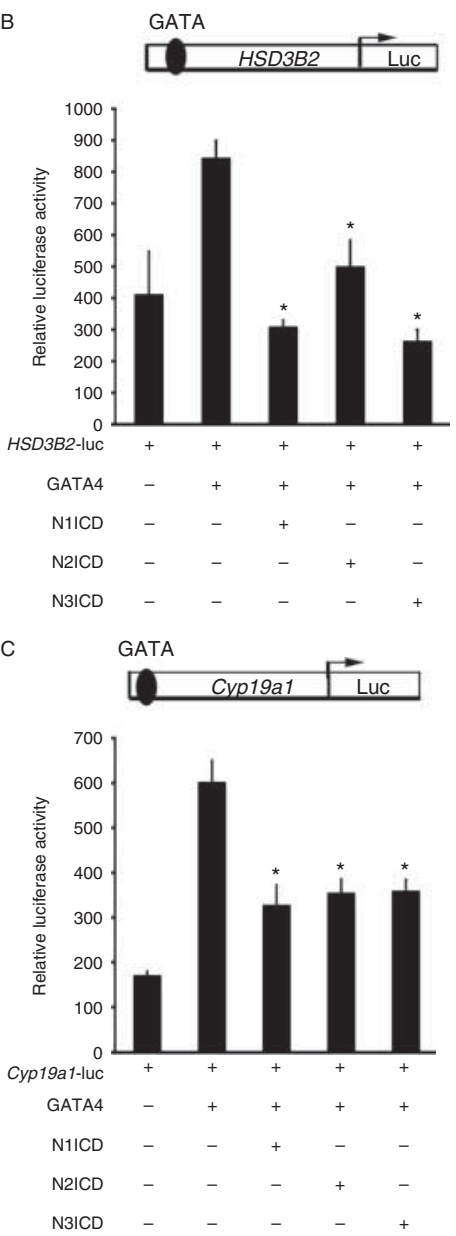

Figure 4 Activated Notch represses GATA4-mediated transcription of steroidogenic enzyme gene promoters. (A, B and C) NIH3T3 cells were transfected with a specific luciferase reporter gene construct, an expression plasmid for GATA4, and a specific activated Notch receptor, as indicated. After $48 \mathrm{~h}$ in culture, cells were lysed and luciferase activity was determined. GATA4 binds to the promoter regions of the Star, HSD3B2, and Cyp19a1 reporter constructs, inducing transcription. The GATA4-induced luciferase activity of each gene was inhibited significantly by co-transfection of Notch $1-3$ ICD $(* P<0.05)$. All data are the results of three experiments done in triplicate \pm s.D. Schematics above the graphs depict the reporter constructs. 


\section{(-259 to +2)Cyp19a1 PII}

GATGATAAGGTTCTATCAGACCAACTGTTGAACAGAACCTGAGCCTCCCAAGGTCATCCTTGTTT TGACTTGTAACCACAAATTTGTCTTGTCTAAGTGTCCAATCACTATAAAACAAAATGCCCATCTC TCCAATCCAGCACCCTTCCAAGTGACAGGAGCCACAGCCAAACCGCTGGGTTACGTTCTAACTCC ACCACTGCTTTCTTCCCATAGAACTTTACTTTTTTTTTTTCTTCTGAGGCCAAATAGCGCAAGA $\mathrm{T}$

\section{$(-224$ to +53$) H S D 3 B 2$}

BCTGTTAAGGCTAAAGCCAAGACTCTTTATCACACTGTGGCCTTAAGATTGGATTTCTCTTCCTG TTCCTGGGAAGAATTAGAGATATAACCTAAAGGTCACTATTATTCTGAGAAAAGGGATTCTGGAG GAGGAGGGAGCAATGAGTATGTGGCAGGAGTTCAAGGTAATAAGGGCTGAGACACAAGCCACAGA GCATAAAGCTCCAGTCCTTCCTCCAGGGATGAGGCAGTAAGGACTTGGACTCCTCTGTCCAGCTT TTAACAATCTAAGTTACG

\section{(-958 to -39) Star}

GGTCAGGACCTGTAGCAGGGCAGGCCAGCCTTAGCTGCATGAGGAAAGGGTGAGCTTGCAGGGTG GAACCCAGGCCTAAGTTACTCTCTGCCTTGAGAGCTTACTGGGTGGGTCATCTCATTTCCAGAGA GTTCCCAGAATGAGAAGTTAGAGTGGAGTTGGTATCAATGGGTGAGCAAATAAATGAAAACTGAA CACATGGGGTGCTCAGGAGGCCCCACATAGAAGGAACCAAGGCCAGCTAGAGGACTTGAGCTATT GTCCTATATTGCCCTAGCCCTGACACTGGCATCCTGTTTGTCTTTGAGCCAGCCATTGATACCCT CCAGACCTGATGGACGGTCTTGCAGGTTTTGTTTGTTTGTTTGTCTGTTTGTTTGTTCTTTTGAG ACAGGGTCATTCTGTGTAGCCCTTGTTGTCCTAAACCTTACTATATAGACCAGGCTGGGCTTGAA CTCACCAGAGATCTACTTGCCTCTGCCAGGGAGAGTATGTGCCACCATGCCTACCTCTGGTCTTG TTGCAAGAACTCACTCTTTGACTCTTTTACCCTGGCTCCCTCTCTTGGCCAGAGCTTCTATATAC TTTTTGATGCACCTCAGTTACTGGGCATTTAAGCGGAGGACAGGGCTTGAAGTCTACATTTACAA CTTTAGAGAAGCTATATATACATATCCTCTGCCCCATCTCCGTGACCCCTGCTTTCCCCTACCTG CAGAGTCTGGTCCTCCCTTTACACAGTCTGCTCCCTCCCACCTTGGCCAGCACTGCAGGATGAGG CAATCATTCCATCCTTGACCCTCTGCACAATGACTGATGACTTTTTTATCTCAAGTGATGATGCA CAGCCTTCCACGGGAAGCATTTAAGGCAGCGCACTTGATCTGCGCCACAGCTGCAGGACTCAGGA CCTTGAAAG

\section{GATA box (confirmed) E boxCANNTG (predicted) N box CACNAG (predicted)}

Figure 5 TFSearch analysis of steroidogenic gene promoters. The sequence of the promoters in each luciferase reporter gene is presented. Each promoter was examined using TFsearch for the presence of $\mathrm{N}$ and $\mathrm{E}$ boxes. All of the GATA sites (blue highlight) have been confirmed in other studies. Cyp19a1 has two E boxes (green highlight), HSD3B2 has an N box (red highlight), and Star has three E boxes and an N box.

represses the Star promoter directly by binding to the E boxes or acts through a complex with GATA4, 3T3 cells were transfected with the Star-luciferase reporter, plasmids expressing GATA4, and either full length HEY2 or one of two mutants (Fig. 7A). The first mutant, HEY2-62, lacks the $\mathrm{N}$ terminus, including the basic domain, but has an intact HLH domain. This mutant can form a dimer and interact with GATA4 but cannot bind DNA on its own (Kathiriya et al. 2004). The second mutant, HEY2-121, lacks both the basic and HLH domains; it can neither dimerize nor bind DNA (Fig. 7A). When co-transfected with GATA4 and the Star-luciferase reporter gene, neither HEY2-62 nor
HEY2-121 could inhibit GATA4-induced transcription (Fig. 7B). These data indicated that Hey proteins likely regulate activation of steroidogenesis genes through specific sites in this promoter.

\section{Discussion}

Follicle maturation and growth includes an increase in the size of the oocyte and the proliferation and differentiation of granulosa cells, leading to antrum formation and increased steroidogenesis. Growth of the follicle is regulated by the interplay of signals between the oocyte and the granulosa cells. A combination of 

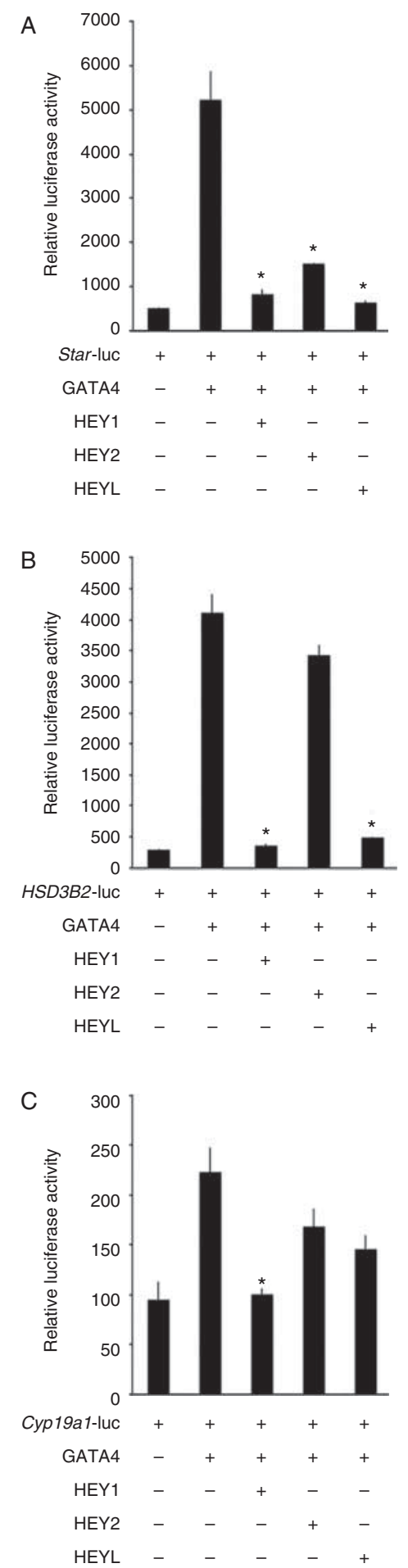

Figure 6 Hey1, Hey2, and Heyl can inhibit promoters of steroid biosynthesis genes. (A, B and C) NIH3T3 cells were transfected with a luciferase reporter gene construct along with expression plasmids for GATA4 and a HEY protein. Cell lysates were made $48 \mathrm{~h}$ posttransfection and luciferase activity determined. GATA4 activates each luciferase reporter to high levels and this is significantly inhibited with specific Hey genes $\left({ }^{*} P<0.05\right.$, over bar). HEY1, HEY2, and HEYL differentially inhibit GATA4 mediated up-regulation of transcription of Star, Cyp19a1, and HSD3B1. All data are the results of three experiments done in triplicate \pm s.D. oocyte factors, FSH, and estradiol are necessary for granulosa cell proliferation in preantral growing follicles (Moor et al. 1980, Robker \& Richards 1998, Britt et al. 2000, Kawashima et al. 2008, Murray et al. 2008, West-Farrell et al. 2009). Notch signaling has been shown to be important for granulosa cell proliferation. Disruption of Notch signaling in conditional mutants of Notch2 and Jag1 in the ovary resulted in a lack of granulosa cell proliferation (Zhang et al. 2011, Vanorny et al. 2014). DAPT, a biomimetic inhibitor that is bound by the presenilin component of $\gamma$-secretase, has been used to disrupt Notch signaling in vitro. This inhibitor preferentially targets amyloid precursor protein and Notch processing by $\gamma$-secretase (Berezovska et al. 2000, Hadland et al. 2001, Yang et al. 2008). Using DAPT to inhibit Notch signaling in ex vivo ovary culture inhibited granulosa cell proliferation and folliculogenesis was halted (Zhang et al. 2011, Manosalva et al. 2013). In our studies, DAPT treatment resulted in the up-regulation of steroid biosynthesis genes in small follicles (Fig. 1).

Based on our data, altered Notch signaling disrupts the normal process of steroid biosynthesis during folliculogenesis, and this is consistent with the defective folliculogenesis noted in $\mathrm{Lfng}^{-/-}$and conditional mutants of Notch2, Jag1, and Hes1 (Hahn et al. 2005, Manosalva et al. 2013, Xu \& Gridley 2013, Vanorny et al. 2014). The data presented here demonstrates that Notch signaling has a role in the complex regulation of the expression of enzymes of the steroid biosynthesis pathway and likely regulates $\mathrm{FSH}$-induced proliferation of granulosa cells (Fig. 1). This is consistent with the role of Notch signaling in other tissues, promotion of proliferation, and regulation of the timing of the fully differentiated state. We propose that the differential response to $\mathrm{FSH}$, proliferation in small preantral follicles, and increased steroidogenesis in larger preantral and antral follicles is regulated, in part, by Notch signaling.

In gonadal cells DAX1, a repressor, and the activator, SF1, regulate expression of multiple genes involved in steroidogenesis, including Cyp19a1 Pll, Star, Cyp11A1, and HSD3B2 (Tremblay \& Viger 2001 a, Wang et al. 2001, Lalli \& Sassone-Corsi 2003, Jo \& Stocco 2004, Manna et al. 2009). Our studies indicated that activated Notch receptors can inhibit steroid synthesis in cAMP-activated MA-10 Leydig cells and in granulosa cells of preantral follicles (Figs 1 and 2), thus it was possible that expression of either factor might be regulated by Notch. For example, Dax 1 transcription could be up-regulated by the NotchICD/RBPJK complex, blocking activation of SF1 and steroidogenesis. Alternatively, SF1 transcription could be inhibited by the HES or HEY repressors, also blocking steroidogenesis. Treatment of MA-10 cells with dbcAMP results in a decrease in DAX1 protein levels, increasing the transcriptional activity of SF1 (Wang et al. 2002, Rao et al. 2003, Jo \& Stocco 2004, Trbovich et al. 2004, Manna et al. 2009). Our observations indicated that 
A

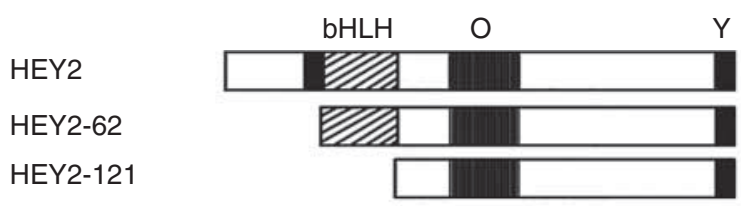

B

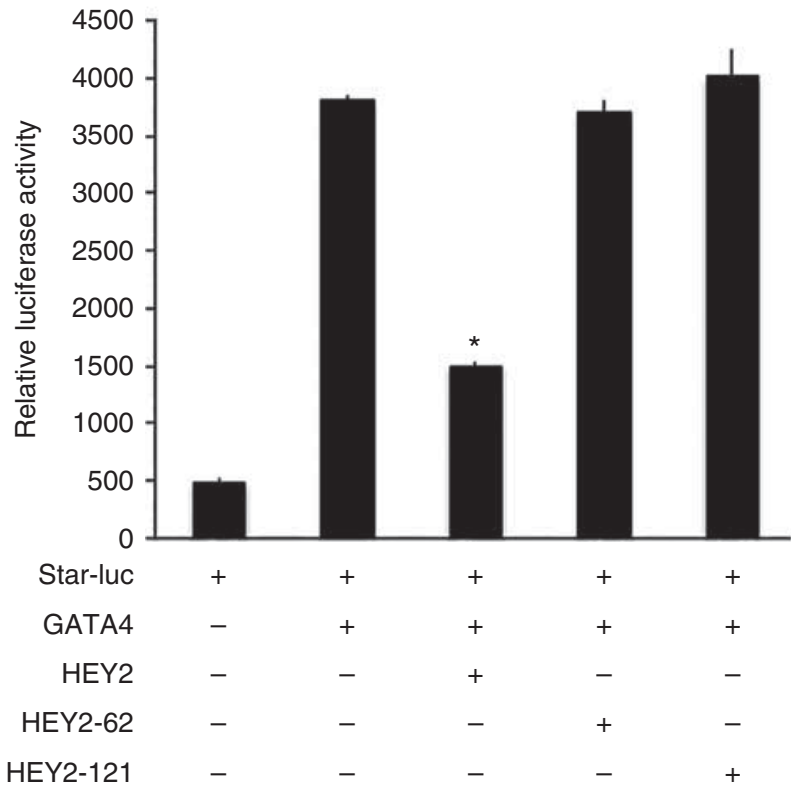

Figure 7 Hey proteins repress gene promoter activity through DNA binding. (A) The truncation mutants HEY2-62 (b) is missing the basic domain only, and HEY2-121 is missing both the basic and helix-loophelix domains (bHLH). (B) NIH3T3 cells were transfected with the Starluciferase reporter along with plasmids that express GATA4 and HEY2, HEY2-62, or HEY2-121. HEY2 significantly inhibited GATA4-induced luciferase activity. The loss of either the basic or bHLH domains of Hey2 resulted in a loss of repression of the Star-luciferase reporter gene $\left({ }^{*} P<0.05\right)$ and indicated that DNA binding was necessary for HEY2mediated inhibition of this promoter. All data are the results of three experiments done in triplicate \pm s.D.

Notch-mediated inhibition of steroid biosynthesis was not achieved by modulating the expression of these two major transcriptional regulators (Fig. 3) but rather by repressing expression of genes that encode important nodal points in gonadal steroid biosynthesis.

Steroidogenesis genes have well-studied promoters that are transactivated by GATA4 (Tremblay \& Viger $2001 a, b$, Tremblay et al. 2002, Viger et al. 2004, 2008, Bergeron et al. 2015, Schrade et al. 2015). All three activated Notch receptors significantly inhibited HSD3B2, Star, and Cyp19a1 promoter activity (Fig. 4). This observation is consistent with work by others that showed that the transactivation ability of GATA4 can be inhibited by Notch through HEY2 (Kathiriya et al. 2004). We determined that the Cyp19a1 PII, HSD3B2, and Star promoters had $\mathrm{E}$ and $\mathrm{N}$ boxes that $\mathrm{HEY}$ repressors could bind (Fig. 5), and subsequent experiments demonstrated that there was a differential inhibition of the promoters. For example, the Star promoter was significantly inhibited by HEY1, HEY2, and HEYL, but the HSD $3 B 2$ promoter, which contains a single $\mathrm{N}$ box, was only inhibited by HEY1 and HEYL (Fig. 6). This is consistent with previous data that demonstrated that HEY2 does not bind to $\mathrm{N}$ boxes with the sequence CACAAG (Nakagawa et al. 2000). Consistently, the Cyp19a1 promoter was not inhibited by HEY2 or HEYL and the $5^{\prime}$ most $\mathrm{E}$ box had a sequence that was not bound by HEY2 in previous studies (Nakagawa et al. 2000). The second E box found in this promoter is very similar in sequence and thus is likely a poor target for the HEY proteins also. These data indicate that direct DNA binding to specific sites in the promoters of these genes by the HEY proteins is likely the mechanism for Notch-mediated regulation of steroidogenesis gene transcription. We further ruled out the likelihood of the HEY repressors acting through complex formation with GATA4 by using mutants of Hey2 (Fig. 7). Our data demonstrated that GATA4-induced luciferase activity was repressed only by full-length HEY2 and not by a mutant that could form a complex with GATA4 but not bind DNA. In previous studies, there were no $\mathrm{N}$ or $\mathrm{E}$ boxes in the promoters examined, so this might indicate that in the absence of direct binding, the HEY repressors will act through complex formation with GATA factors (Kathiriya et al. 2004, Shirvani et al. 2006).

Determining that the genes necessary for steroid biosynthesis in developing follicles and Leydig cells are Notch targets is a novel observation with important implications. Notch signaling is important for the development of the male reproductive tract, and Leydig cells particularly (Dirami et al. 2001, Tang et al. 2008, Hahn et al. 2009, Defalco et al. 2013). Perturbation of Notch signaling in granulosa cells results in MOFs, defective meiotic maturation, and loss of oocytes (Hahn et al. 2005, Trombly et al. 2008, Manosalva et al. 2013, Xu \& Gridley 2013, Vanorny et al. 2014). Because Notch2, Notch3, and Jag2 are not expressed in the oocyte, it is logical to conclude that these defects arise because altered Notch signaling disrupted the reciprocal communication between the oocyte and granulosa cells. Also, GATA factors have important roles in gonad development and the function and regulation of steroid biosynthetic genes (Viger et al. 2008, Padua et al. 2014, 2015, Tevosian 2014, Bergeron et al. 2015, Schrade et al. 2015). Conditional alleles of Gata4 resulted in impaired fertility in both adult female and male mice, Gata $^{-1-}$ ovaries ovulated fewer oocytes and developed ovarian cysts, and there was decreased Cyp19a1 expression (Kyrönlahti et al. 2011a). When Gata4 and Gata6 are simultaneously deleted in granulosa cells, there is a complete lack of proliferation and no follicular development in the adult (Padua et al. 2014). Knockdown or deletion of Gata4 in Leydig cells resulted in decreased expression of genes involved in cholesterol synthesis and transport and steroid biosynthesis 
(Bergeron et al. 2015, Schrade et al. 2015). The disruption of GATA4 function or conditional loss of Gata4 in Sertoli cells in adult males also resulted in a loss of fertility and repression of steroid biosynthesis genes (Kyrönlahti et al. 2011b, Schrade et al. 2014, Bergeron et al. 2015, Padua et al. 2015). HEY2 has been demonstrated to be an important factor in the regulation of GATA-mediated transactivation of cardiac specific genes (Kathiriya et al. 2004, Fischer et al. 2005), and our data implicates the HEY proteins in the regulation of steroidogenesis postnatally. Because Notch genes are expressed in adrenal glands (de Mendonca et al. 2014) and the developing pituitary (Goldberg et al. 2011), the possibility that alterations to the Notch pathway can affect steroidogenesis and potentially the hypothalamicpituitary-gonadal axis will be an important future consideration.

\section{Declaration of interest}

The authors declare that there is no conflict of interest that could be perceived as prejudicing the impartiality of the research reported.

\section{Funding}

This work was funded in part by NICHD grant HD39850-01 to J Wilson-Rawls.

\section{Acknowledgements}

The authors would like to thank Drs Raphael Kopan, Kathy Loomes, and Mario Ascoli for reagents.

\section{References}

Ascoli M 1981 Regulation of gonadotropin receptors and gonadotropin responses in a clonal strain of Leydig tumor cells by epidermal growth factor. Journal of Biological Chemistry 256 179-183.

Baker PJ \& O'Shaughnessy PJ 2001 Role of gonadotrophins in regulating numbers of Leydig and Sertoli cells during fetal and postnatal development in mice. Reproduction 122 227-234. (doi:10.1530/rep.0. 1220227)

Baker PJ, Pakarinen P, Huhtaniemei IT, Abel MH, Charlton HM, Kumar TR \& O'Shaughnessy PJ 2003 Failure of normal Leydig cell development in follicle-stimulating hormone $(\mathrm{FSH})$ receptor-deficient mice, but not FSH $\beta$-deficient mice: role for constitutive FSH receptor activity. Endocrinology 144 138-145. (doi:10.1210/en.2002-220637)

Belandia B, Powell SM, García-Pedrero JM, Walker MM, Bevan CL \& Parker MG 2005 Hey1, a mediator of notch signaling, is an androgen receptor corepressor. Molecular and Cellular Biology 25 1425-1436. (doi:10.1128/MCB.25.4.1425-1436.2005)

Berezovska O, Jack C, McLean P, Aster JC, Hicks C, Xia W, Wolfe MS, Weinmaster G, Selkoe DJ \& Hyman BT 2000 Rapid Notch1 nuclear translocation after ligand binding depends on presenilin-associated $\gamma$-secretase activity. Annals of the New York Academy of Sciences 920 223-226. (doi:10.1111/j.1749-6632.2000.tb06926.x)

Bergeron F, Nadeau G \& Viger RS 2015 GATA4 knockdown in MA-10 Leydig cells identifies multiple target genes in the steroidogenic pathway. Reproduction 149 245-257. (doi:10.1530/REP-14-0369)

Bouchard MF, Taniguchi H \& Viger RS 2005 Protein kinase A-dependent synergism between GATA factors and the nuclear receptor, liver receptor homolog-1, regulates human aromatase (CYP19) PII promoter activity in breast cancer cells. Endocrinology 146 4905-4916. (doi:10.1210/en. 2005-0187)

Britt KL, Drummond AE, Cox VA, Dyson M, Wreford NG, Jones MEE, Simpson ER \& Findlay J 2000 An age-related ovarian phenotype in mice with targeted disruption of Cyp 19 (Aromatase) gene. Endocrinology 141 2614-2623. (doi:10.1210/endo.141.7.7578)

Chin MT, Maemura K, Fukumoto S, Jain MK, Layne MD, Watanabe M, Hsieh CM \& Lee ME 2000 Cardiovascular basic helix loop helix factor 1 , a novel transcriptional repressor expressed preferentially in the developing and adult cardiovascular system. Journal of Biological Chemistry 275 6381-6387. (doi:10.1074/jbc.275.9.6381)

Cortvrindt R, Smitz J \& Van Steirteghem AC 1997 Assessment of the need for follicle stimulating hormone in early preantral mouse follicle culture in vitro. Human Reproduction 12 759-768. (doi:10.1093/ humrep/12.4.759)

Defalco T, Saraswathula A, Briot A, Iruela-Arispe ML \& Capel B 2013 Testosterone levels influence mouse fetal Leydig cell progenitors through Notch signaling. Biology of Reproduction 88 91. (doi:10.1095/ biolreprod.112.106138)

Dirami G, Ravindranath N, Achi MV \& Dym M 2001 Expression of Notch pathway components in spermatogonia and Sertoli cells of neonatal mice. Journal of Andrology 22 944-952. (doi:10.1002/j1939-4640. 2001.tb03434.x)

Elagib KE, Xiao M, Hussaini IM, Delehanty LL, Palmer LA, Racke FK, Birrer MJ, Shanmugasundaram G, McDevitt MA \& Goldfarb AN 2004 Jun blockade of erythropoiesis: role for repression of GATA-1 by HERP2. Molecular and Cellular Biology 24 7779-7794. (doi:10.1128/MCB.24. 17.7779-7794.2004)

Fischer A, Klattig J, Kneitz B, Diez H, Maier M, Holtmann B, Englert C \& Gessler M 2005 Hey basic helix-loop-helix transcription factors are repressors of GATA4 and GATA6 and restrict expression of the GATA target gene ANF in fetal hearts. Molecular and Cellular Biology 25 8960-8970. (doi:10.1128/MCB.25.20.8960-8970.2005)

Goldberg LB, Aujla PK \& Raetzman LT 2011 Persistent expression of activated notch inhibits corticotrope and melanotrope differentiation and results in dysfunction of the HPA axis. Developmental Biology 358 23-32. (doi:10.1016/j.ydbio.2011.07.004)

Grogan SP, Olee T, Hiraoka K \& Lotz MK 2008 Repression of chondrogenesis through binding of notch signaling proteins HES-1 and HEY-1 to N-box domains in the COL2A1 enhancer site. Arthritis and Rheumatism 58 2754-2763. (doi:10.1002/art.23730)

Gurates B, Amsterdam A, Tamura M, Yang S, Zhou J, Fang Z, Amin S, Sebastian S \& Bulun SE 2003 WT1 and DAX-1 regulate SF-1-mediated human P450arom gene expression in gonadal cells. Molecular and Cellular Endocrinology 208 61-75. (doi:10.1016/S03037207(03)00198-9)

Hadland BK, Manley NR, Su D, Longmore GD, Moore CL, Wolfe MS, Schroeter EH \& Kopan R 2001 Gamma-secretase inhibitors repress thymocyte development. PNAS 98 7487-7491. (doi:10.1073/pnas. 131202798)

Hahn KL, Johnson J, Beres BJ, Howard S \& Wilson-Rawls J 2005 Lunatic fringe null female mice are infertile due to defects in meiotic maturation. Development 132 817-828. (doi:10.1242/dev.01601)

Hahn KL, Beres B, Rowton MJ, Skinner MK, Chang Y, Rawls A \& WilsonRawls J 2009 A deficiency of lunatic fringe is associated with cystic dilation of the rete testis. Reproduction 137 79-93. (doi:10.1530/REP08-0207)

Haimes J \& Kelley M 2010 Demonstration of a $\Delta \Delta C$ q calculation method to compute relative gene expression from qPCR data. ThermoScientific Tech Note 1-4.

Heikinheimo M, Ermolaeva M, Bielinska M, Rahman NA, Narita N, Huhtaniemi IT, Tapanainen JS \& Wilson DB 1997 Expression and hormonal regulation of transcription factors GATA-4 and GATA-6 in the mouse ovary. Endocrinology 138 3505-3514. (doi:10.1210/endo. 138.8.5350)

Heinemeyer T, Wingender E, Reuter I, Hermjakob $H$, Kel AE, Kel $O$, Ignatieva EV, Ananko EA, Podkolodnaya OA \& Kolpakov F 1998 Databases on transcriptional regulation: TRANSFAC, TRRD and COMPEL. Nucleic Acids Research 26 362-367. (doi:10.1093/nar/26.1.362)

Heisig J, Weber D, Englberger E, Winkler A, Kneitz S, Sung W-K, Wolf E, Eilers M, Wei C-L \& Gessler M 2012 Target gene analysis by microarrays 
and chromatin immunoprecipitation identifies HEY proteins as highly redundant bHLH repressors. PLoS Genetics 8 e1002728. (doi:10.1371/ journal.pgen.1002728)

Holderfield MT \& Hughes CCW 2008 Crosstalk between vascular endothelial growth factor, Notch, and transforming growth factor-in vascular morphogenesis. Circulation Research 102 637-652. (doi:10. 1161/CIRCRESAHA.107.167171)

Ishiko E, Matsumura I, Ezoe S, Gale K, Ishiko J, Satoh Y, Tanaka H, Shibayama H, Mizuki M, Era T et al. 2005 Notch signals inhibit the development of erythroid/megakaryocytic cells by suppressing GATA-1 activity through the induction of HES1. Journal of Biological Chemistry 280 4929-4939. (doi:10.1074/jbc.M406788200)

Iso T, Kedes L \& Hamamori Y 2003 HES and HERP families: multiple effectors of the Notch signaling pathway. Journal of Cellular Physiology 194 237-255. (doi:10.1002/jcp.10208)

Ito M, Yu R \& Jameson JL 1997 DAX-1 inhibits SF-1-mediated transactivation via a carboxy-terminal domain that is deleted in adrenal hypoplasia congenita. Molecular and Cellular Biology 17 1476-1483.

Jarriault S, Brou C, Logeat F, Schroeter EH, Kopan R \& Israël A 1995 Signalling downstream of activated mammalian Notch. Nature 377 355-358. (doi:10.1038/377355a0)

Jo Y \& Stocco DM 2004 Regulation of steroidogenesis and steroidogenic acute regulatory protein in R2C cells by DAX-1 (dosage-sensitive sex reversal, adrenal hypoplasia congenita, critical region on the $\mathrm{X}$ chromosome, gene1). Endocrinology 145 5629-5637. (doi:10.1210/en.2004-0941)

Johnson J, Espinoza T, McGaughey RW, Rawls A \& Wilson-Rawls J 2001 Notch pathway genes are expressed in mammalian ovarian follicles. Mechanisms of Development 109 355-361. (doi:10.1016/S09254773(01)00523-8)

Kageyama R \& Nakanishi S 1997 Helix-loop-helix factors in growth and differentiation of the vertebrate nervous system. Current Opinion in Genetics \& Development 7 659-665. (doi:10.1016/S0959437X(97)80014-7)

Kathiriya IS, King IN, Murakami M, Nakagawa M, Astle JM, Gardner KA, Gerard RD, Olson EN, Srivastava D \& Nakagawa O 2004 Hairy-related transcription factors inhibit GATA-dependent cardiac gene expression through a signal-responsive mechanism. Journal of Biological Chemistry 279 54937-54943. (doi:10.1074/jbc.M409879200)

Kawashima I, Okazaki T, Noma N, Nishibori M, Yamashita Y \& Shimada M 2008 Sequential exposure of porcine cumulus cells to $\mathrm{FSH}$ and/or LH is critical for appropriate expression of steroidogenic and ovulation-related genes that impact oocyte maturation in vivo and in vitro. Reproduction 136 9-21. (doi:10.1530/REP-08-0074)

Kokubo H, Miyagawa-Tomita S \& Johnson RL 2005 Hesr, a mediator of the Notch signaling, functions in heart and vessel development. Trends in Cardiovascular Medicine 15 190-194. (doi:10.1016/j.tcm.2005.05.005)

Kopan R \& Ilagan MXG 2009 The canonical Notch signaling pathway: unfolding the activation mechanism. Cell 137 216-233. (doi:10.1016/j. cell.2009.03.045)

Kreeger PK, Fernandes NN, Woodruff TK \& Shea LD 2005 Regulation of mouse follicle development by follicle-stimulating hormone in a three-dimensional in vitro culture system is dependent on follicle stage and dose. Biology of Reproduction 73 942-950. (doi:10.1095/biolreprod.105.042390)

Kwintkiewicz J, Cai Z \& Stocco C 2007 Follicle-stimulating hormoneinduced activation of Gata4 contributes in the up-regulation of Cyp19 expression in rat granulosa cells. Molecular Endocrinology 21 933-947. (doi:10.1210/me.2006-0446)

Kyrönlahti A, Vetter M, Euler R, Bielinska M, Jay PY, Anttonen M, Heikinheimo M \& Wilson DB 2011 a GATA4 deficiency impairs ovarian function in adult mice. Biology of Reproduction 84 1033-1044. (doi:10. 1095/biolreprod.110.086850)

Kyrönlahti A, Euler R, Bielinska M, Schoeller EL, Moley KH, Toppari J, Heikinheimo M \& Wilson DB 2011b GATA4 regulates Sertoli cell function and fertility in adult male mice. Molecular and Cellular Endocrinology 333 85-95. (doi:10.1016/j.mce.2010.12.019)

Laitinen M, Anttonen M \& Ketola I 2000 Transcription factors GATA-4 and GATA- 6 and a GATA family cofactor, FOG-2, are expressed in human ovary and sex cord-derived ovarian tumors. Journal of Clinical Endocrinology and Metabolism 85 3476-3483. (doi:10.1210/jcem.85.9.6828)

Lalli E \& Sassone-Corsi P 2003 DAX-1, an unusual orphan receptor at the crossroads of steroidogenic function and sexual differentiation. Molecular Endocrinology 17 1445-1453. (doi:10.1210/me.2003-0159)
Leal MC, Surace EI, Holgado MP, Ferrari CC, Tarelli R, Pitossi F, Wisniewski T, Castaño EM \& Morelli L 2012 Notch signaling proteins HES-1 and Hey-1 bind to insulin degrading enzyme (IDE) proximal promoter and repress its transcription and activity: implications for cellular A $\beta$ metabolism. Biochimica et Biophysica Acta 1823 227-235. (doi:10.1016/j.bbamcr.2011.09.014)

Leimeister C, Dale K, Fischer A, Klamt B, Hrabé de Angelis M, Radtke F, McGrew MJ, Pourquié O \& Gessler M 2000 Oscillating expression of c-Hey2 in the presomitic mesoderm suggests that the segmentation clock may use combinatorial signaling through multiple interacting bHLH factors. Developmental Biology 227 91-103. (doi:10.1006/dbio.2000.9884)

Lenie S, Cortvrindt R, Adriaenssens T \& Smitz J 2004 A reproducible twostep culture system for isolated primary mouse ovarian follicles as single functional units. Biology of Reproduction 71 1730-1738. (doi:10.1095/ biolreprod.104.028415)

Lu FM \& Lux SE 1996 Constitutively active human Notch1 binds to the transcription factor CBF1 and stimulates transcription through a promoter containing a CBF1-responsive element. PNAS 93 5663-5667. (doi:10.1073/pnas.93.11.5663)

Lupien M, Diévart A, Morales CR, Hermo L, Calvo E, Kay DG, Hu C \& Jolicoeur P 2006 Expression of constitutively active Notch1 in male genital tracts results in ectopic growth and blockage of efferent ducts, epididymal hyperplasia and sterility. Developmental Biology $\mathbf{3 0 0}$ 497-511. (doi:10.1016/j.ydbio.2006.09.010)

Manna PR, Dyson MT, Jo Y \& Stocco DM 2009 Role of dosage-sensitive sex reversal, adrenal hypoplasia congenita, critical region on the $\mathrm{X}$ chromosome, gene 1 in protein kinase $\mathrm{A}$ - and protein kinase $\mathrm{C}$-mediated regulation of the steroidogenic acute regulatory protein expression in mouse Leydig tumor cells: mechanism of action. Endocrinology 150 187-199. (doi:10.1210/en.2008-0368)

Manosalva I, González A \& Kageyama R 2013 Hes1 in the somatic cells of the murine ovary is necessary for oocyte survival and maturation. Developmental Biology 375 140-151. (doi:10.1016/j.ydbio.2012. 12.015)

Martin LJ, Taniguchi H, Robert NM, Simard J, Tremblay JJ \& Viger RS 2005 GATA factors and the nuclear receptors, steroidogenic factor $1 /$ liver receptor homolog 1 , are key mutual partners in the regulation of the human $3 \beta$-hydroxysteroid dehydrogenase type 2 promoter. Molecular Endocrinology 19 2358-2370. (doi:10.1210/me.2004-0257)

de Mendonca POR, Costa IC \& Lotfi CFP 2014 The involvement of Nek2 and Notch in the proliferation of rat adrenal cortex triggered by POMCderived peptides. PLOS ONE 9 e108657. (doi:10.1371/journal.pone. 0108657)

Mizutani T, Shiraishi K, Welsh T \& Ascoli M 2006 Activation of the lutropin/choriogonadotropin receptor in MA-10 cells leads to the tyrosine phosphorylation of focal adhesion kinase by a pathway that involves Src family kinases. Molecular Endocrinology 20 619-630. (doi:10.1210/me.2005-0277)

Moor RM, Polge C \& Willadsen SM 1980 Effect of follicular steroids on the maturation and fertilization of mammalian oocytes. Journal of Embryology and Experimental Morphology 56 319-335.

Murray AA, Gosden RG, Allison V \& Spears N 1998 Effect of androgens on the development of mouse follicles growing in vitro. Journal of Reproduction and Fertility 113 27-33. (doi:10.1530/jrf.0.1130027)

Murray AA, Swales AKE, Smith RE, Molinek MD, Hillier SG \& Spears N 2008 Follicular growth and oocyte competence in the in vitro cultured mouse follicle: effects of gonadotrophins and steroids. Molecular Human Reproduction 14 75-83. (doi:10.1093/molehr/gam092)

Nakagawa O, McFadden DG, Nakagawa M, Yanagisawa H, Hu T, Srivastava D \& Olson EN 2000 Members of the HRT family of basic helix-loop-helix proteins act as transcriptional repressors downstream of Notch signaling. PNAS 97 13655-13660. (doi:10.1073/pnas. 250485597)

Niwa Y, Shimojo H, Isomura A, González A, Miyachi H \& Kageyama R 2011 Different types of oscillations in Notch and Fgf signaling regulate the spatiotemporal periodicity of somitogenesis. Genes and Development 25 1115-1120. (doi:10.1101/gad.2035311)

Ong C-T, Cheng H-T, Chang L-W, Ohtsuka T, Kageyama R, Stormo GD \& Kopan R 2006 Target selectivity of vertebrate notch proteins. Collaboration between discrete domains and CSL-binding site architecture determines activation probability. Journal of Biological Chemistry 281 5106-5119. (doi:10.1074/jbc.M506108200) 
Padua MB, Jiang T, Morse DA, Fox SC, Hatch HM \& Tevosian SG 2014 Simultaneous gene deletion of Gata4 and Gata6 leads to early disrution of follicular development and germ cell loss in the murine ovary. Endocrinology 91 1-10. (doi:10.1210/en.2014-1907)

Padua MB, Jiang T, Morse DA, Fox SC, Hatch HM \& Tevosian SG 2015 Combined loss of the GATA4 and GATA6 transcription factors in male mice disrupts testicular development and confers adrenal-like function in the testes. Endocrinology 156 1873-1886. (doi:10.1210/en.2014-1907)

Payne AH \& Hales DB 2004 Overview of steroidogenic enzymes in the pathway from cholesterol to active steroid hormones. Endocrine Reviews 25 947-970. (doi:10.1210/er.2003-0030)

Ragazzon B, Lefrançois-Martinez A-M, Val P, Sahut-Barnola I, Tournaire C, Chambon C, Gachancard-Bouya J-L, Begue R-J, Veyssière G \& Martinez A 2006 Adrenocorticotropin-dependent changes in SF-1/DAX-1 ratio influence steroidogenic genes expression in a novel model of glucocorticoidproducing adrenocortical cell lines derived from targeted tumorigenesis. Endocrinology 147 1805-1818. (doi:10.1210/en.2005-1279)

Rao RM, Jo Y, Leers-Sucheta S, Bose HS, Miller WL, Azhar S \& Stocco DM 2003 Differential regulation of steroid hormone biosynthesis in R2C and MA-10 Leydig tumor cells: role of SR-B1-mediated selective cholesteryl ester transport. Biology of Reproduction 68 114-121. (doi:10.1095/ biolreprod.102.007518)

Robker RL \& Richards JS 1998 Hormonal control of the cell cycle in ovarian cells: proliferation versus differentiation. Biology of Reproduction $\mathbf{5 9}$ 476-482. (doi:10.1095/biolreprod59.3.476)

Sasai Y, Kageyama R, Tagawa Y, Shigemoto R \& Nakanishi S 1992 Two mammalian helix-loop-helix factors structurally related to Drosophila hairy and enhancer of split. Genes and Development 6 2620-2634. (doi:10.1101/gad.6.12b.2620)

Schimmer BP \& White PC 2010 Minireview: Steroidogenic factor 1: its roles in differentiation, development, and disease. Molecular Endocrinology 24 1322-1337. (doi:10.1210/me.2009-0519)

von Schönfeldt V, Wistuba J \& Schlatt S 2004 Notch-1, c-kit and GFR $\alpha-1$ are developmentally regulated markers for premeiotic germ cells. Cytogenetic and Genome Research 105 235-239. (doi:10.1159/ 000078194)

Schrade A, Kyrönlahti A, Akinrinade O, Pihlajoki $M$, Häkkinen $M$, Fischer S, Alastalo T-P, Velagapudi V, Topparif J, Wilson DB et al. 2015 GATA4 is a key regulator of steroidogenesis and glycolysis in mouse Leydig cells. Endocrinology 156 1860-1872. (doi:10.1210/en. 2014-1931)

Shirvani S, Xiang F, Koibuchi N \& Chin MT 2006 CHF1/Hey2 suppresses SM-MHC promoter activity through an interaction with GATA-6. Biochemical and Biophysical Research Communications 339 151-156. (doi:10.1016/j.bbrc.2005.10.190)

Spears N, Murray AA, Allison V, Boland NI \& Gosden RG 1998 Role of gonadotrophins and ovarian steroids in the development of mouse follicles in vitro. Journal of Reproduction and Fertility 113 19-26. (doi:10.1530/jrf.0.1130019)

Takata T \& Ishikawa F 2003 Human Sir2-related protein SIRT1 associates with the bHLH repressors HES1 and HEY2 and is involved in HES1and HEY2-mediated transcriptional repression. Biochemical and Biophysical Research Communications 301 250-257. (doi:10.1016/ S0006-291X(02)03020-6)

Tang H, Brennan J, Karl J, Hamada Y, Raetzman L \& Capel B 2008 Notch signaling maintains Leydig progenitor cells in the mouse testis. Development 135 3745-3753. (doi:10.1242/dev.024786)

Tevosian SG 2014 Transgenic mouse models in the study of reproduction: insights into GATA protein function. Reproduction 148 R1-R14. (doi:10. 1530/REP-14-0086)

Trbovich AM, Martinelle N, O'Neill FH, Pearson EJ, Donahoe PK, Sluss PM \& Teixeira J 2004 Steroidogenic activities in MA-10 Leydig cells are differentially altered by CAMP and Müllerian inhibiting substance. Journal of Steroid Biochemistry and Molecular Biology 92 199-208. (doi:10.1016/j.jsbmb.2004.07.002)

Tremblay JJ \& Viger RS 2001a Nuclear receptor Dax-1 represses the transcriptional cooperation between GATA-4 and SF-1 in Sertoli cells. Biology of Reproduction 64 1191-1199. (doi:10.1095/ biolreprod64.4.1191)

Tremblay JJ \& Viger RS 2001 b GATA factors differentially activate multiple gonadal promoters through conserved GATA regulatory elements. Endocrinology 142 977-986. (doi:10.1210/endo.142.3.7995)
Tremblay JJ, Hamel F \& Viger RS 2002 Protein kinase A-dependent cooperation between GATA and CCAAT/enhancer-binding protein transcription factors regulates steroidogenic acute regulatory protein promoter activity. Endocrinology 143 3935-3945. (doi:10.1210/en. 2002-220413)

Trombly D, Woodruff T \& Mayo K 2008 Suppression of Notch signaling in the neonatal mouse ovary decreases primordial follicle formation. Endocrinology 150 1014-1024. (doi:10.1210/en.2008-0213)

Vanorny DA, Prasasya RD, Chalpe AJ, Kilen SM \& Mayo KE 2014 Notch signaling regulates ovarian follicle formation and coordinates follicular growth. Molecular Endocrinology 28 499-511. (doi:10.1210/ me.2013-1288)

Viger RS, Mertineit C, Trasler JM \& Nemer M 1998 Transcription factor GATA-4 is expressed in a sexually dimorphic pattern during mouse gonadal development and is a potent activator of the Müllerian inhibiting substance promoter. Development 125 2665-2675.

Viger RS, Taniguchi H, Robert NM \& Tremblay JJ 2004 Role of the GATA family of transcription factors in andrology. Journal of Andrology 25 441-452. (doi:10.1002/j.1939-4640.2004.tb02813.x)

Viger RS, Guittot SM, Anttonen M, Wilson DB \& Heikinheimo M 2008 Role of the GATA family of transcription factors in endocrine development, function, and disease. Molecular Endocrinology 22 781-798. (doi:10. 1210/me.2007-0513)

Vorontchikhina MA, Zimmermann RC, Shawber CJ, Tang H \& Kitajewski J 2005 Unique patterns of Notch1, Notch4 and Jagged1 expression in ovarian vessels during folliculogenesis and corpus luteum formation. Gene Expression Patterns 5 701-709. (doi:10.1016/j.modgep.2005. 02.001)

Wang ZJ, Jeffs B, Ito M, Achermann JC, Yu RN, Hales DB \& Jameson JL 2001 Aromatase (Cyp19) expression is up-regulated by targeted disruption of Dax1. PNAS 98 7988-7993. (doi:10.1073/pnas. 141543298)

Wang XJ, Dyson MT, Mondillo C, Patrignani Z, Pignataro O \& Stocco DM 2002 Interaction between arachidonic acid and CAMP signaling pathways enhances steroidogenesis and StAR gene expression in MA-10 Leydig tumor cells. Molecular and Cellular Endocrinology 188 55-63. (doi:10.1016/S0303-7207(01)00748-1)

West-Farrell ER, Xu M, Gomberg MA, Chow YH, Woodruff TK \& Shea LD 2009 The mouse follicle microenvironment regulates antrum formation and steroid production: alterations in gene expression profiles. Biology of Reproduction 80 432-439. (doi:10.1095/biolreprod.108.071142)

Wooten-Kee CR \& Clark BJ 2000 Steroidogenic factor-1 influences protein deoxyribonucleic acid interactions within the cyclic adenosine 3,5monophopshate-responsive regions of the murine steroidogenic acute regulatory protein gene. Endocrinology 141 1345-1355. (doi:10.1210/ endo.141.4.7412)

Xiang F, Sakata Y, Cui L, Youngblood JM, Nakagami H, Liao JK, Liao R \& Chin MT 2006 Transcription factor CHF1/Hey2 suppresses cardiac hypertrophy through an inhibitory interaction with GATA4. American Journal of Physiology. Heart and Circulatory Physiology 290 H1997-H2006. (doi:10.1152/ajpheart.01106.2005)

Xu J \& Gridley T 2013 Notch2 is required in somatic cells for breakdown of ovarian germ-cell nests and formation of primordial follicles. BMC Biology 11 13. (doi:10.1186/1741-7007-11-13)

Yang T, Arslanova D, Gu Y, Augelli-Szafran C \& Weiming X 2008 Quantification of $\gamma$-secretase modulation differentiates inhibitor compound selectivity between two substrates Notch and amyloid precursor protein. Molecular Brain 1 15-28. (doi:10.1186/17566606-1-15)

Zhang C-P, Yang J-L, Zhang J, Li L, Huang L, Ji S-Y, Hu Z-Y, Gao F \& Liu Y-X 2011 Notch signaling is involved in ovarian follicle development by regulating granulosa cell proliferation. Endocrinology 152 2437-2447. (doi:10.1210/en.2010-1182)

Received 18 May 2015

First decision 18 June 2015

Revised manuscript received 9 July 2015

Accepted 16 July 2015 